\title{
Determining the stability of minimally displaced lateral humeral condyle fractures in children: ultrasound is better than arthrography
}

\author{
Andreas Rehm* ${ }^{*}$, Tamás Kobezda and Elizabeth Ashby
}

We read with interest the recent publication by $\mathrm{Wu}$ and colleagues [1]. Weiss et al. [2] defined a classification system and treatment for lateral humeral condyle fractures (LHCF) based on fracture displacement and articular congruity: (1) type I displaced $<2 \mathrm{~mm}$ : nonoperative treatment; (2) type II displaced $\geq 2 \mathrm{~mm}$ with intact articular cartilage as seen on arthrogram (all 65 fractures had $\geq 2-<4 \mathrm{~mm}$ displacement): closed reduction and percutaneous pinning (CRPP); (3) type III displaced $\geq 2 \mathrm{~mm}$ with articular cartilage not intact (all 93 fractures had $\geq 4 \mathrm{~mm}$ displacement on radiographs and were thought to have a disrupted articular cartilage without this having been confirmed by arthrogram or intraoperative findings: open reduction and K-wire fixation (ORIF). The minor/major complication rate was much higher in the type III (23/9) than the type II group (6/1).

Bernthal et al. [3] reported on 141 LCHFs, 76 treated non-operatively, 14 with CRPP and 51 with ORIF. Those treated with CRPP or ORIF had a significantly reduced absolute arc of motion up to 18 weeks after injury compared to non-operative treatment. Nazareth et al. [4] reported significantly reduced Pediatric Outcomes Data Collection Instrument (PODCI) scores for type II/III fractures at 6 and 12 weeks compared to type I fractures.

Li et al. [5, 6] being the same authors as Wu et al. [1] previously reported that the lateral humeral cartilage

*Correspondence: leoreporting@yahoo.co.uk

Paediatric Division, Department of Paediatric Orthopaedics, Cambridge

University Hospitals NHS Trust, Hills Road, Cambridge CB2 0QQ, UK hinge and fracture stability can be accurately determined with transverse ultrasound (US), based on US examinations performed on children with LHCFs treated between February 2013 and May 2019, without the need for arthrograms.

Li et al. [5] stated that the US technique is simple, safe, inexpensive and the most advanced method for determining fracture stability compared to MRI and arthrography and can effectively avoid inadequate treatment and unnecessary surgery for fractures with $2-4 \mathrm{~mm}$ displacement with intact articular cartilage. Of 39 fractures with 2-4 mm displacement 14 had an intact articular cartilage as seen on US and were treated non-operatively without further displacement. This indicates that possibly all of Weiss et al.s 65 type II fractures could have been treated safely without surgery.

Li et al. [5] recommended the routine use of their US technique. Considering the former information, we agree with Li et al.s [5] recommendation that US should be introduced as a routine investigation which could change how we manage LHCFs in the future, pushing the frontier of safe non-operative treatment from the below $<2 \mathrm{~mm}$ to the $\geq 2-<4 \mathrm{~mm}$ group with intact articular cartilage. This could result in a substantial benefit for this patient group since they would be managed without anaesthetic, would not be exposed to surgical risks and would have a quicker functional recovery [3, 4], with cost savings for overstretched health services.

Despite the same authors [5] having shown that cartilage integrity can be identified accurately purely by original author(s) and the source, provide a link to the Creative Commons licence, and indicate if changes were made. The images or other third party material in this article are included in the article's Creative Commons licence, unless indicated otherwise in a credit line to the material. If material is not included in the article's Creative Commons licence and your intended use is not permitted by statutory regulation or exceeds the permitted use, you will need to obtain permission directly from the copyright holder. To view a copy of this licence, visit http://creativecommons.org/licenses/by/4.0/. The Creative Commons Public Domain Dedication waiver (http://creativecommons.org/publicdomain/zero/1.0/) applies to the data made available in this article, unless otherwise stated in a credit line to the data. 
using US with the child awake without the need for an arthrogram and it being safe to manage fractures with intact cartilage non-operatively in cast, Wu et al. [1] only described US as a complementary tool with arthrography to assess the integrity of the cartilage hinge. We would like to ask $\mathrm{Wu}$ et al. [1] why they started using arthrography in May 2018 under general anaesthetic after having successfully used only US for over 5 years previously and why they performed CRPP on 25 children with $\geq 2-<4 \mathrm{~mm}$ displacement with intact articular cartilage in contrary to them having previously reported that there was neither a need to expose these children to an anaesthetic for an arthrogram nor the need to perform CRPP $[5]$ ?

\section{Abbreviations}

LHCF: Lateral humeral condyle fractures; CRPP: Closed reduction and percutaneous pinning; ORIF: Open reduction and K-wire fixation; PODCI: Pediatric Outcomes Data Collection Instrument; US: Ultrasound.

\section{Acknowledgements}

None.

\section{Authors' contributions}

AR contributed to the literature review and manuscript preparation. TK contributed to the literature review and manuscript preparation. EA contributed to the literature review and manuscript preparation. All authors read and approved the final manuscript.

Funding

None.

\section{Availability of data and materials}

Not applicable.

\section{Declarations}

Ethics approval and consent to participate Not applicable.
Consent for publication

Not applicable.

\section{Competing interests}

The authors declare that they have no competing interests.

Received: 19 October 2021 Accepted: 21 October 2021

Published online: 30 November 2021

\section{References}

1. Wu X, Li X, Yang S, Wang S, Xia J, Chen XL, Shen X. Determining the stability of minimally displaced lateral humeral condyle fractures in children: ultrasound is better than arthrography. J Orthop Surg Res. 2021:16(1):32. https://doi.org/10.1186/s13018-020-02174-8.

2. Weiss JM, Graves S, Yang S, Mendelsohn E, Kay RM, Skaggs DL. A new classification system predictive of complications in surgically treated pediatric humeral lateral condyle fractures. J Pediatr Orthop. 2009;29:602-5.

3. Bernthal NM, Hoshino CM, Dichter D, Wong M, Silva M. Recovery of elbow motion following pediatric lateral condylar fractures of the humerus. J Bone Jt Surg Am. 2011;93:871-7.

4. Nazareth A, Schur M, Schroeder AJ, Whitlock PW, Skaggs DL, Goldstein RY. Obesity as a predictor of outcomes in type III \& IV supracondylar humerus fractures. J Orthop Trauma. 2021. https://doi.org/10.1097/BOT.00000 00000002081.

5. Li X, Shen X, Wu X, Chen X. A novel transverse ultrasonography technique for minimally displaced lateral humeral condyle fractures in children. Orthop Traumatol Surg Res. 2019;105(3):557-62.

6. $L i X$, Shen $X$, Wu X, Zhou Z. The routine cutoff displacement of $2 \mathrm{~mm}$ may not reliably reflect the stability of pediatric lateral humeral condyle fractures. Injury. 2020;51:2588-91.

\section{Publisher's Note}

Springer Nature remains neutral with regard to jurisdictional claims in published maps and institutional affiliations.
Ready to submit your research? Choose BMC and benefit from:
- fast, convenient online submission
- thorough peer review by experienced researchers in your field
- rapid publication on acceptance
- support for research data, including large and complex data types
- gold Open Access which fosters wider collaboration and increased citations
- maximum visibility for your research: over 100M website views per year
At BMC, research is always in progress.
Learn more biomedcentral.com/submissions 